\title{
A READING OF INTERPRETATIVE MODELS OF MINIMALISM IN ARCHITECTURE \\ Vladimir STEVANOVIC*
}

Received: 10.09.2012; Final Text: 10.12.2013

Keywords: minimalism in architecture; contemplation; consumerism; modernism; postmodernism; minimal art.

1. The term existential minimum (egzistenz minimum) refers to the minimum of living space in social housing in the context of rehabilitation and reconstruction in Germany after World War I. This is of concern to the architectural model of Neue Sachlichkeit, which was supposed to symbolize a spirit of cost-efficiency, functionality and rationality of the modern age (Frampton, 1992, 130-141).
* Department of History, Theory and Aesthetics of Architecture and Visual Arts, Faculty of Architecture, University of Belgrade, SERBIA.

\section{INTRODUCTION}

In architectural discourse, outside of the context of Frankfurt existential minimum,(1) the term minimalism appears in the second half of the 70s. Articles of professional journals and chapters of editions used the term to describe morphological aspects of the works of individual or more architects. Being a minimalist, in common sense supposed architecture of primary and simple - minimal geometric forms. Formal orientation of then current Legorreta, Kahn and Ando, was determined as minimalism (Smith, 1976; Bonnefoi, 1979; Taki, 1984). Leading historians, during the 80s, also sporadically use the term in monographic reviews of modern architecture. Jencks $(1982$; 1987) does it when he speaks of reviving of purism in the works of the New York Five and ascetic style of fundamental Platonic forms of neorationalist Rossi and Ungers. In a similar way, Curtis (1982) comments on the cold abstraction and strict minimalist tendencies in Scandinavian architecture.

\section{FIRST WRITINGS: CREATING A MYTH}

Noticeable expansion of a new figurative phenomenon in architectural practice in the late $80 \mathrm{~s}$, takes on considerable reflection on the theoretical level. In those years starts the writing about minimalism in architecture as a tendency, not as individual manifestations. It becomes clear that a new topic is established in architectural theory. From then onwards, in theoretical considerations on minimalism in architecture there is a certain number of consistent hypotheses, which over time acquired a status of typical interpretative patterns. However, these patterns constantly reiterated, do not come from nowhere and have not been there always. One could ask is there any specific author, text or publication, responsible for theoretical promotion of minimalism in architectural discourse. Where did it all begin? A comprehensive chronological analysis of literature - primary references dealing with minimalist theory, point to December 1988, when 
2. Constant relocations of architects through different stylistic formations is not something uncommon, which is emphasized by Goldhagen (2005) when she notes that the formal preferences of an architect might change even in course of his or her life. Nevertheless, the particular nature of this case is reflected in the fact that the same works of certain architects, belonging to the same period, at the same time pervate throughout the discourses of minimalism, critical regionalism, neo-rationalism etc.

3. It is significant that the theme of the connection between minimal art and minimalism in architecture in this edition belonged art theorists such as Donald Kuspit and Germano Celant (Celant, 1988; Kuspit, 1988).

4. In this context Bonnefoi (1979) remarks on the relationship between Kahn brutalist architecture and minimal art, which are realized through common strategy of equal treatment of formal and structural solutions.

5. Phenomenology is a philosophical direction, stipulated by its founder Edmund Husserl, that opposes a positivistic, abstractly-scientific view of the world. Phenomenology proposes immediate, intuitive knowledge, whereby the pure consciousness is intentionally focused on the essence of the observed subject.

6. This topic is often discussed in the context of Ando. Taki (1984) interprets Ando's minimalist monotonousness as refusal of values of consumer society and turing to the spirituality of Japanese tradition.

7. Rassegna 36/4: Minimal in short notes and bibliography lists appears together with the German edition Daidalos 30: Pathosformeln in der Architectur (Formulae of Pathos in Architecture), as one of the first journals that thematically treated minimalism in architecture. While Savi and Montaner (1996, 176) and Macarthur $(2005,105,108)$ refer to both issues, Melhuish (1994, 10), Bertoni $(2002,221)$ and Ruby et al $(2003,26)$ include only Rassegna. The truth is that only Rassegna was dedicated exclusively to minimalism, because Daidalos contains only one text that explicitely uses the term.
Italian architectural journal Rassegna publishes the thematic issue titled Minimal.

Before the author of the editorial, architect and theorist of neorationalist Venetian school Gregotti, there were two matters of importance for creating a myth on the new style: 1) altisonant, explicit and representative denomination - minimalism, or in Macarthur's $(2005,101)$ words: to say in a word what picture says and; 2) gathering as many architects as possible. Accordingly, in addition to the already mentioned Ando, Kahn, Ungers, in the same line, among others, there were: Isozaki, Barragan, Siza, Souto de Moura, Alejandro de la Sota Martinez, Herzog and DeMeuron, Nouvel, Valle, Snozzi and Gregotti himself. It is interesting that minimalist works of many aforementioned architects already existed, before declaration of minimalism, though as a part of architectural historiography in some other sense. For instance, Frampton (1983) already spoke about Kahn, Barragan, Snozzi, Ando, Gregotti, Ungers and Siza in terms of critical regionalism, while Jencks (1987) studies Ungers within postmodern fundamentalists. Symptomatic was the appropriation of architects under the auspices of minimalist discourse with the purpose of theoretical establishment of a new topic (2).

For Gregotti, architectural minimalism is a part of a broader tendency to suppress what is excessive in artistic practice, on the basis of discovering elementary, archetypal gestures. As one of the goals of Minimal issue, he pointed out historical placement and analysis of theoretical influences. In this sense, Gregotti emphasizes formal and poetic relations with American minimal art (3) from the 60s and the tradition of European avantgarde and modern architecture. Avon and Vragnaz deal with the aspects of minimalism in architecture, common point of different author concepts, recognized in the Mediterranean region (Italy, Spain and Portugal), Switzerland and Japan. These are extreme formal simplification and reduction to minimal geometry, as well as absence of elements that can: 1) suggest function and dimension - impression of multifunctionality and ascalarity; 2) provoke emotion - neutrality, and; 3) transfer a symbolic message - absence of meaning and self-reference. Literal use of material is also a significant aspect (4). Bodily sensitivity and tactile experience are accentuated in the context of phenomenological perception (5). In the space of reduction, comprised only of primary architectural elements, light and material, the relation between the user and spatial unit is intensified. Movement, touch and look gain specific significance when formal complications do not come to the fore. If in the European context it was insisted on certain historical influences, Japan was a completely different story. Here Avon and Vragnaz relate minimalism with an experience of emptiness, originating from Buddhist tradition. As a key of Japanese minimalism there was a spirit of the wabi - moral principle, which advocates voluntary poverty and simple life. Wabi is based on a Zen concept, according to which separation from material possessions leads toward self-realization and self-liberation (6). At the end, most Rassegna authors coincide in an estimation that minimalist reduction represents a call for resistance against postmodern eclectic assembly and decorative hypertrophy.

On one hand, almost forgotten and now hard-to-find Milan edition had insignificant impact on further theorization of minimalism in architecture. This allegation is complemented by the fact that Rassegna texts were cited in only several points in other theorists (7). However, from today's 
perspective, we can say that the majority of dominant research approaches on minimalism in architecture is unified in that very journal. Theoretical contribution to this field greatly relies on identification, interpretation and criticism of what is written in Rassegna.

\section{THEORETICAL DEVELOPMENT}

During the 90s, the constitution of theoretical framework included formal analyses, definitions, classifications of architects, as well as cultural and national backgrounds, in which minimalism was detected. The debate took place for the most part in Italian, Spanish and English journals. Architectural journals Lotus International, El Croquis and Architectural Design Profile, following Rassegna's example, print thematic issues. In the mid 90s the first monographs appear (Carmagnola, Pasca, 1996; Savi, Montaner, 1996; Pawson, 1996; Ypma, 1996).

Montaner (1993) states the characteristics of minimalism: the picturesque minimal, geometrical rigor, the ethics of repetition, technical precision and materiality, unity and simplicity, the distortion of scale, predominance of structual form and pure present. From London emerge several definitions of minimalism: 1) essentially a reductionist architecture which comprises simplicity, linearity, subdued palette of colors, level of finish and contemplation (Vice, 1994, 15); 2) perfection and quality an object achieves once it can no longer be improved by subtraction and when all the components, details and joints are reduced to the essence (Pawson, 1996, 7) and; 3) reduction of architecture to the primordial concepts of space, light and mass (Murray, 1999, 8).

In the 90s some new architects appear. They also soon became minimalists, together with the authors whose work was known already in 1988, but was not mentioned in Rassegna. It is indicative that there was no mention of London minimalism in Italian and Spanish publications, where we could hear of local-Mediterranean, Swiss and Japanese minimalism. Possible reason for this is the fact that English minimalism first developed through smaller designs and architecture of the interior. Pawson, Silvestrin and Freton are specialists for interiors of apartments, boutiques, restaurants, galleries and family homes, while Chiperfield is known for larger buildings. In this sense, London theorists never failed to show how London minimum is underestimated in the world public (Melhuish, 1994, 13; Ypma, 1996, 13). However, London theorists exhaustively pointed to other areas where minimalism in architecture was developing. As leading figures of Swiss essentialists Buchenan (1991) affirms Herzog and DeMeuron. In the Mediterranean region, in the Iberian Peninsula there is a mention of Souto de Moura and Baeza. Melhuish (1994) as features of Mediterranean minimalism allocates connection with the location, handcrafting in comparison to the industrial manufactory and tradition of white, simple, rational architecture incorporated into the landscape. Vice (1994) finds that the Japanese climate, tradition and lifestyle are acceptable for the minimalist formula. These considerations open questions on origin and affiliation of minimalism in terms of tradition, which causes some theorists to appropriate minimalism to their own cultures. Ypma (1996) draws a English reductionist line: from Victorian architecture of elegant restraint and simple use of highest-quality material, over technological standardization in circumstances of industrial revolution, to the new brutalism of the years 50 of XX century. For Ypma minimalism is a true London style, conceived in this city in the 80s, as a part of English national 
8. This way MoMA confirms the epitom of the right place for pompous presentation of new architectural tendencies. In that sense we can compare the importance of the ehxibition Light construction with the exhibitions International Style (1932) and Deconstructivism (1988), held in this institution.

9. Ibelings $(1988,57)$, Prestinenza $(2008,86)$ and Malgrave and Goodman (2011, 195, 215) refers to both exibitions, while Savi and Montaner $(1996,178)$ mentions only Monolitic architecture. characters. On the other hand, Ranzo (Carmagnola, Pasca, 1996, 149) finds the archetype of minimalism in vernacular Mediterranean architecture.

Media presentation with the new style in the mid 90s transfers from Europe to America, in form of organized exhibitions. In New York's MoMA,(8) the exhibition called Light construction (1995) curated by Riley, shows architectural works of strict rectangular volumes, which realize the new architectural sensibility and withdrawal from formal-rhetorical incidents. That same year, in Pittsburgh, Machado and el-Khoury organize the exhibition Monolithic architecture. The topic are objects that look like as if they were made in a single piece, solid, massive structure of great eloquence in spite of limited formal means (Machado, el-Khoury, 1995). Even though the term minimalism is not particularly stressed, both exhibitions are important link in the chain of texts (9).

This constitutional period of theoretical development is followed by critical review of established minimalist theory. The main topics set in Rassegna still remain: historical line, ethical aspects, relations with modernism, minimal art and postmodernism, as well as self-reference which produces phenomenological experience of minimalist space.

\section{CONTEMPLATION / CONSUMERISM}

Study of Japanese spirituality related to minimalism in architecture is introduction to highlighting the elements of theology and tradition in theoretical treatises. After Taki (1984) and Avon and Vragnaz (1988), contemplative values are pointed by Auer $(1988,100)$. He understands Japanese minimalism as an ode to emptiness, moral encouragement and a call for humility and self-realization. The most influential English minimalist architect, Pawson, got to know the wabi ideal directly during his four-year stay in Japan. In addition to that, his fascinations are empty, purified, ascetic space of medieval Cistercian monasteries, which as such allow undisturbed worship of God, and a life radically dedicated to material poverty and spiritual wealth preached by the Protestant sect of Quakers. Pawson integrates sources of inspiration in his book Minimum (1996). Here the concepts of simplicity, reduction and essence are represented as the key of understanding, the necessary state and basic quality of minimalism, and most importantly - common ideal of many different cultures.

Symptomatic for argumentation which takes the postulates of ascetic religions and sects is the belief that minimalist, as a simple architecture, based on selective process of reduction, helps people discover their true desires and essential needs of life. This way, minimalism functions as a universal phenomenon of rejection of materiality and an orientation towards spirituality and essence. These theses carry specific meaning because they are created in times truly marked with: 1) economic recession and energy deficit; 2) obstinate exploitation of natural resources, growing environmental crisis and pollution, and; 3) mass consumption and cultural contamination. With regard to this, London theorists gradually develop a mixture of socially engaged and psychological-ethical reading: minimalist reduction is represented as a remedy for all victims of consumerist society and a metaphor of saving, both of architectural ornaments and world resources. While Vice (1994) understands minimalism in architecture as a reaction to consumerism of the 80s, Glancey (1990) critiques bogging down in possessions, which encourages people to fill their spaces with 
unnecessary things. The superabundance of mass culture visual effects results in a search for a quiet oasis in an overcrowded and visually loud environment. The contrast between the quiet and the loud in terms of architectural visuality is represented as a triumph of minimalist sophistication over consumerism. For the same reasons Ympa (1996) does not see minimalism as a style, rather sees it as a philosophy of life, which offers visual peace in the chaos of urban life. For Toy $(1999,7)$ minimalism is a perceptive therapy for liberation from everyday hustle and relaxing in the peaceful paradise of elegant simplicity. In this theoretical line, the Italian designer Vignelli (Bertoni, 1999, 226) is the most pompous. He suggests that minimalism is not a style, it is a behavior, a way of being, fundamental reaction to visual noise, disorder and vulgarity. It is the longing for the essence of things, rather than their appearance.

Minimum significantly influenced the Spanish and Italian theorists. In a Pawson manner, Zabalbeascoa and Marcos (2000) and Bertoni (2002) provide chronological maps of cycles in reductive culture, pointing the study of minimalism backwards, toward everything that contained concepts of simple, reduced, empty, spiritual, essential and modest. Bertoni's approach follows manifestation of reduction, expressive clarity, rigorous essentiality, mental purity and formal simplicity; regardless of the social-historical context and whether it is architecture or a mindset in other areas of culture. This historical-associative theory line is oriented exclusively towards the search for the precursors of minimalism. The criterion is any coincidence, and the goal to establish as many arbitrary connections with minimalist tradition as possible. Synthesizing the spirituality of transcendence and dissatisfaction with the time in which the glorification of material assets in contrast with usefulness and necessity, Zabalbeascoa and Marcos further develop the ethical aspect of minimalism, which can be called contemplation in consumerism. They understand the formal nature of minimalism as zeitgeist, suggesting purification and reduction as most eloquent gestures in the era showered with images, shapes and sounds. For Bertoni, minimalism in architecture transcends the resistance to consumerist culture and becomes a promotion of life in spirituality, clarity and harmony. The most dedicated to this kind of theorization, Bertoni perceives minimalism as ethics of simplicity. In this sense, moral integrity of minimalism supposes that: 1) an authentic, simple and instantaneous act of perception of basic psychological and physical values, such as time, space and silence, opens a dialog with the spiritual dimension and;2) mental, spatial and timeless emptiness allow for a pause for reflection and a different perspective of reality. The aim is to get to know a more peaceful, more dignified and valuable lifestyle, where at the top of the pyramid there are universal qualities that belong to ordinary, simple and everyday things. Minimalism is the manifestation of this lifestyle and ethical prevalence between: 1) defeating materialism, weight of possession and all that is inauthentic, excessive, deceitful and irrelevant and; 2) a quest for spirituality, real values in life and essence. Suppression and rejection of the first and concentration to the second, according to Bertoni, eliminates modern noise and sets the foundations of a new principle of progress.

Paradoxical transfer of ideas from traditional and religious culture to a mass commodity culture was inspiring for the critics of this theory. The relation between metaphysical and economic aspect is emphasized in Jenks, who understands the term of minimalism as bourgeois version of late modern movement. Through his aphorism minimalism lends itself 
to spirituality, but it also lends itself to shopping (Murray, 1999, 16), Jenks alludes that the spirituality is manifested in materiality of most expensive commercial architecture of London. Similar skepticism was expressed by Vice (1994), comparing the voluntary and conditioned simplicity, i.e., minimalism for the design and minimalism for the necessity imposed by economic poverty.

\section{MODERNISM: REVIVAL, SURVIVAL OR STYLE OF XX CENTURY}

One of the trajectory of theorization positions minimalism as repetition of modernist style. Theorists refer to two periods in terms of modernist reminiscence: 20 s as heroic era of modern movement, and; 60 s as culmination of international style.

Minimalism in architecture, in early 90s in London, was considered a revival of non-ornamentalism, clear space and beauty of simple elegance, in the continuity of mythical unfinished project of early modernism of the 20s (Toy, 1994, 7; Melhuish, 1994, 11). Since the topics here are the interior and a family home, the affirmation of Loos and Corbusier as precursors of minimalism is understandable. The new formal idiom of restrained, strict, neutral and peaceful architecture, emerged is the second half of the 80s, Glancey (1990) denominates minimal new moderns and announces it as the style of the 90s. The same phenomenon Jencks (1990a, 1990b) observes in a range: twenties revivalism; late modern movement; neo-modern aesthetics, and as forefather of minimalism he sees van der Rohe.

The repertoire of form, appearing in the modern movement unambiguously corresponds to the work of the new minimalist generation of architects. Nevertheless, following the approach of Goldhagen (2005), it seems necessary to indicate that there is a significant difference between the attitudes towards morphological aspects within the discursive field. A simple abstract geometry in the 20s represented a metaphor of the battle for liberation from bourgeois ornamental historicism and tradition in a broader sense, while the technology was glorified due to cheap and rapid production processes, which instilled faith in social progress based on industrial and machine development. In this context Gregotti $(1988,8)$ assessed the technology as a natural field rather than a field of reconsideration for minimalist architects. In comparison to the ideology of modernist social housing program, with a change of social context, typical user of modernist/minimalist architecture also changed. London Minimal new moderns is detected by Glancey (1990) as just the opposite - a new lifestyle of wealthier class. Former utilitarian ethics became a lifestyle of local bourgeoisie, apartment and commercial space owners. As utopian tensions disappeared over time, the image of the modern survived without epochal references, reduced to material phenomena (Avon, Vragnaz, 1988, 32). Aware of this are the theorists who consider minimalism in the context of different manifestation of this modern image. In addition to social connotations, Wölfflinian relation between modernism and minimalism can be resolved in a plan of perception (Melhuish, 1994, 11; Zabalbeascoa and Marcos, 2000, 107). Functional ideology of mechanical and industrial era produced a machine for living, with clear but cold and aseptic space. On the other hand, minimalism avoids the impression of coldness using tactile material qualities and texture subtlety. Sensory and bodily experience of non-cluttered space is underlined. In this context Auer $(1988,99)$ notes how the spirit of geometry has to move from calculations to emotions, from head to the body. 
10. The exhibition was organized by Collegi $d^{\prime}$ Arquitectes de Catalunya withit XIX Congress of the International Union of Architects (UIA) that took place in 1996 in Barcelona. The proposal for organization and the initiative to award the exhibition to Col-legi were the idea of the general secretary of XIX Congress, de Sola Morales.
At the exhibition Less is More (10) (1996), Savi and Montaner showcase works of architecture and other arts. The two curators in the exhibition catalog put forth the hypothesis that in the development of architecture there are moments of crisis which cyclically reiterate and require a review of fundamental disciplinary concepts (Savi, Montaner, 1996, 9). In their opinion, these reviews resulted in returning to the starting point and zero degree of architecture, which comprises refusing the ornaments and seeking for the essence. In XX century, modern tradition with specific simple and restrained morphology takes the role of classical architecture, as eternal style. In this way, minimalism is a part of a broader selfunderstandable linear inevitability in the interchange and reiteration of styles. This is a cyclical return to the pure form after formalistic excess that happened several times in the history of architecture, though under different names (Gothics-Rennaissance, Rococo-Neoclassicism etc).

Behrens's and Mies's phrases less is more and bienahe nichts are represented as operative principles of minimalism. XX century for these authors is the century of minimalist simplicity, and less is more is its fundamental and atemporal principle.

Ibelings (1988) and Macarthur (2002) understand minimalism as a kind of nostalgia for the 60s. As Jencks and Glancey, Macarthur (2002, 146, 2005, 106) places minimalism in the frame of neomodernism (or the second modernism), which he at the same time considers a more proper term. He repetitively puts the word minimalism under quotation marks - so called "minimalist" architecture. Ibelings groups the mini-movements, which seek the absolute zero in architecture (monolitic architecture, light construction, less is more) under the name of supermodernism. He believes that the architecture he refers to in this context is a superlative version of modern commercial architecture of the 60s, casually observing that today's minimalism is much purer than ever owing to improvement of technology and material (Ibelings, 1998, 51). In the same context it is also the opinion of Zabalbeascoa and Marcos $(2000,14)$ on minimalism as a type of modernism sublimed in formal aspect, i.e., the last step of modernism hidden under the shiny mask of technological progress, new materials and handicraft quality. They interpret minimalism as revised and corrected version in comparison to the crisis of modernism as uniform and commercialized international style. However, for Ibelings (1998, 33-41) internationalism, as ideal of belonging to one global community and quintessential element of modernity of 50s and 60s, takes on a new meaning in the context of globalization of the 90s. The idea of an internationally applicable style is appreciated for the same reasons that it used to be criticized in the 70s and 80 s, thus becoming a key in understanding supermodernism. Since, owing to global communications, in the 90s the international ideal was actualized, minimalism can be understood as nostalgia, not only for the architecture of the $60 \mathrm{~s}$, but for the then current cultural climate.

\section{POSTMODERNISM: NEUTRALITY OR WALLPAPERIZATION}

In numerous places minimalism in architecture was regarded as rupture from postmodern turbulence and a relief in comparison to the formalistic excess of the 80s (Avon,Vragnaz, 1988; Melhuish, 1994; Nicolin,1994; Riley,1995). For Auer $(1988,96)$ minimalism and postmodernism stand as binary opposites: emptiness-opulence, silence-semantical plaver, timeless elemental-speed of use. Nevertheless, the fact is that the minimalist discourse in architecture historically belongs to the postmodernist era. Therefore, although the genesis could be followed from several angles, the 
frame remains the postmodernist consumerist society in which there is: 1) a mass culture, with byproducts such as kitsch, populism and glorification of commodity; 2) a late capitalist economy, and; 3) an absence of ideology. In terms of architecture, postmodernism can be defined as: 1) the classicizing style inspired by historicism, figuration and easily comprehensible symbolic ornamentalism; 2) school of thought based on semiotic, linguistic, symbolic and communicative paradigms. The broadness of these postulates allows understanding minimalism outside of the usual forcing of the critique of postmodernism in terms of a face of mass consumption. In this sense, we will present two theoretical approaches.

On the one hand, minimalism is not about resistance to extravagant visuality, as much as taking a stance of neutrality toward the symbolic components of postmodernism. How Ibelings (1998) notes, minimalism/ supermodernism is a neutral and non symbolic architecture, empty medium that does not contain any message and that can stand anywhere in a global world. Jenks (2002) also examines minimalist architecture in the context of a consumer society, where both traditional and religious, as well as modern outlooks disappear. Therefore, the absence of ideological beliefs and credible public conventions led the architects to turn to the expressions of neutrality and zero degree minimalism. Speaking in terms of Ibelings, the neutrality is related to the context of postmodern theory, while Jenks's neutrality is a result of the missing ideological component in the postmodern social triangle.

The second hypothesis is that minimalism is not the opposite, but the product of postmodernism, and as such, it is developing like any other commodity in the postmodern conditions. In this context, Macarthur $(2002,137)$ finds minimalism the current architectural fashion, which is the result of changes in taste compared to the postmodern notion of architecture as a system of relations and references. Like Jencks and Ibelings, Macarthur sees minimalist buildings as physical objects, determined by their own hylomorphism, in a neomodern style. As the space between lifestyle magazines, architectural periodicals and real estate advertisements becomes smaller than ever, the architecture shown on the front pages looking like canonized modernism, by Macarthur assumes the same ontological status as anything else that is advertised and sold. That is why it appropriate to talk about the commodity character of minimalist neutrality. Macarthur adds that neomodernism/ minimalism cleared of socio-ideological connotations and historical memory of high modernism, uses a dead formal vocabulary. In this light, Grimshaw (2004) sharply criticizes the minimalism as a fetishized modernism promoted as the symbol of good taste by lifestyle journals (a phenomenon he calls Wallpaperization). Using the term soft modernism, he sees minimalism as a humanized version of modernist boxes, where the order, control and discipline survived, but not the sterility. According to Grimshaw, minimalism is casual modernism, inauthentic and kitschy retro-modernism, which exists only as a cliché without original context and theory.

Some theorists do not find grounds for this form of criticism, at least not in the initial phase of minimalism. They speak of a later decadence and vulgarization, not accepting that the modernist mannerism was present from the very beginning. Toy (2000) considers trend-focused journalism as a double-edged sword. A positive effect was marginal detection of the minimalist phenomenon to the general public. On the other hand, copying 
11. Besides the theorists of architecture, in forming this unitary concept also participated the authors who have treated minimalism as general cultural phenomenon. (Obendorf, 2009; VanEenoo, 2011).

12. Greenberg follows the Kantian theory of abstraction of sensuality from the surrounding factors, by idealizing modern art in relation to extra-painting interests. The emphasis is on isolating the pure aesthetic experience to perceptual appearance, without relation to other experiences and knowledge. In this sense, Greenberg institutionalized modern art around the concepts of the autonomy of art and the autonomy of artistic disciplines. Disciplinary autonomy includes: 1) Lessingian medium specific - a norm that ensures no interference of different disciplinary standards, and: 2) the program that defines the character of the work within the media. For Greenberg, the medium of modernist painting is a flat surface. Flatness is an ontological category, a specifical property that painting does not share with any other art. The required postulate includes an abstract and gestural use of color and form (Battcock, 1968; Meyer, 2000).

13. Constructing a material and visua phenomenon that is neither painting nor sculpture but only a specific object, minimalists exceed the limits of the autonomy of the media. Also they reject the abstract painting on a flat two-dimensional surface and research of formal disciplinary possibilities as restrictive and they choose a concrete, literal spatiality. of the most superficial aspects of minimalism easily impressed a wider audience, which, in order to establish personal status, reaches for a new iconography without thinking about the purpose and the real reason. For Ruby $(2003,22)$, the notion of minimalism changed due to its performance, it became the incarnation of a materialistic culture, to which it was a critical alternative. Bertoni $(2006,94)$ also believes that minimal design starts as a lonely, elitist and marginal research, whereas in the 90s it becomes a tendency, with the risk of distancing from its original goals.

\section{MINIMAL ART: A MALAPROPISM}

Minimalism in architecture bears a name used by the American art critics in the 60s in order to unify a certain type of artistic creation of authors such as Judd, Morris, Flavin and Andre. Relations of contemporary minimalism in architecture and minimal art are problematic, despite the tendencies that represent minimalism as a transdisciplinary alteration in the domains of minimal art, literature, dance, music, costume design and architecture (11). Architectural discourse mainly accepts this unitary concept. But since the use of the term minimalism for purely formalistic purposes would be meaningless, it was necessary to find a theoretical point of connection. This was supported by Foster's (1986) interpretation of neutrality of minimal art towards the social context as the product of resistance to the then existing gluttony of consumer society and popular culture. Therefore, in both cases there is an analogy of the literal and self-referential property in socio-cultural terms. The idea of minimalism as a concept shared between art and architecture is complemented by the joint historical hierarchy in comparison to the radically non-minimal styles immediately preceding (abstract expressionism in painting and architectural postmodernism), which is followed by a departure from theoretical frames of these styles (Greenberg's artistic autonomy of high modernism (12), and postmodern linguistic concept of semiotics). In this transdisciplinary focus minimal art is functioning as a link between architectural modernism and minimalism. In this sense, the connecting of minimalism in architecture and minimal art, is most often based on their positioning in a broader framework of the tendency of less is more in art and architecture of the 20th century, which allegedly runs continuously in a reductive and abstract development line: European avantgarde and modern architecture, American neoavantgarde (minimal art) and recent minimalism in architecture. For the sake of analysis of this, as Ursprung (Ruby et al, 2003, 7) ironically puts it naturally given affinity, below follows a brief presentation of the crtitical attitude minimal art takes towards Greenberg's theory: 1) examination of the limits of aesthetic autonomy - the primacy of existence and plastic presence of the very work as a tautological proposition, radically directing the effects towards the perception of volume, and not towards the meaning (what you see is what you see) and; 2) violation of the autonomy of the media, and refusal of the required postulate about abstract reduction of the painting medium to its basic components - shape and color (13). The first aspect automatically excludes ethical and idealistic parallels, considering that it is based on literalism and anti-transcendentalism. Another aspect refutes their common origin of the abstract and reductive. Minimal art is against elegant abstraction, in terms of modernist reduction to a minimum of primary geometric forms, i.e., to the most elemenatry concepts of space, light and mass, as is the case in architecture. Minimal art is not a reductive concept, because there is a significant difference between: 1) the zero degree of reductive abstraction that produces minimal meanings and; 
2) the literal abstraction which is actually only a creative strategy with abstract aspects of objects in a literal sense. For Urpsprung and Macarthur, the key difference between the theoretical level of artistic and architectural minimalism lies in the attitude towards the modernism. The question posed is: does the use of the minimalist theory in architecture suppose the rupture of minimalist achitecture from modernism in the way the minimalist artists did with Greenberg's formalist modernism? (Macarthur, 2005, 106). While minimal art is the antithesis of modernism, it is clear that architectural minimalism, as neo-modernism, has no criticism of modernist values.

The parallel open to interpretation is a question of phenomenological perception. A characteristic of minimal art is the work with primary geometric volumes, which exist equally in relation to the real space in which they are situated and to the bodily presence of the observer, provoking perceptual possibilities. These simple objects, which do not trigger emotions and associativity, can stimulate the observer to: 1) become more conscious of the very act of perception; 2) ask himself of the nature of the art itself, given that the work of art encountered with is no way different from quotidian objects. A simple form does not mean a simple experience in a minimalist triangle, in which there is nothing but the silent object, observer and the space, a work of art is actually the very process of perception. That is why Krauss critiques formalistic apprehension of minimalist concept in architecture without taking into account the phenomenological reception as the quintessential characteristic of minimal art. Krauss $(1996,134)$ considers the use of the term minimalism appropriate exclusively for an artistic approach focused on how the observer sees a work in a specific context. This is also pointed out by Macarthur $(2000,48)$ when he asks can a work of architecture be minimalist in such a way. Perhaps it can, for the architectural concept of phenomenology (14) is: the multisensory and not oculocentric way of perception of buildings, with an emphasis on bodily and haptic experience. When he talks about a self-sufficient architecture without symbolic and metaphorical allusions, Ibelings $(1988,89,94)$ does not reject an a priori concept of meaning. The architecture which does not refer to anything outside itself, and does not address the intellect, automatically prioritizes the immediate, sensual experience of space, light and materials, and the meaning comes from how the object is experienced visually, tactilely, bodily and spatially.

14. Following Husserl, phenomenology
develops oscillating between ontological existential, physiological and poetic modifications. Important author for the architectural understanding of phenomenology is Maurice MerleauPonty, with his idea of direct perception of a concrete/ lived space (Holl et al., 1994; Pallasmaa, 2005).

15. The term minimal art comes from Richard Wollheim's concept of designating minimum conditions under which something can be considered a work of art. Here, Wollhaim's categorization does not even refer to the works of the so called minimalists of the $60 \mathrm{~s}$, it rather refers to the works of authors that precede what the history of art will call minimal art: Marcel Duchamp, Robert Rauschenberg and Ad Reinhard (Wollheim, 1965).

To further confusion about the name contributes the fact that the architects, in terms of inspiration, were not familiar with the American phenomenon. One of the most exploited minimalists, Baeza (Grimmer, 2009) believes that he was improperly attributed with the minimalist label, stating that being abstract and essential does not mean being a minimalist. In this context, Linder $(2004,4)$ estimates that the presumed affinity recent minimal architecture and artistic work in the 60s are more a question of visual similarity than development of specific circumstances and motivations that inspired the artists of the 60s. Perhaps borrowing the name on the basis of commonsense formalist obviousness would be acceptable, if for the same reasons the minimal art got its name (15). It seems that the theory of minimal art in the context of architecture is as futile as the once literal translation of semiotics and deconstruction. 


\section{CONCLUSIONS}

Although still insufficiently defined, in recent years the topic of minimalism enters the historical and theoretical reviews of contemporary architecture. For example, Prestinenza (2008) presents the minimalist tendency, architects and their works, while Mallgrave and Goodman (2011) study a number of minimalisms divided in chapters: 1) materials and effects - testing new materials and their sensory effects; 2) neomodernism - simplicity in shaping forms taken from high modernism and;3) phenomenological architecture - testing phenomenological nature of the experience of architecture itself. However, the approach to minimalism in architecture that supposes reading of its interpretative models, allowed getting closer to the answer to a rather important question of what is the raison d'etre of minimalism at the very moment of its emergence. Discursive analyses impose minimalism as an architectural form of critique, i.e., a response to specific social circumstances, such as mass consumption, economic recession, materialistic commodity culture and the postmodern kitsch and populism. To support this opinion, certain ethical elements of history, ascetic religions and tradition are affirmed. On the other hand, the question remains whether all this is just an attempt to show minimalism in any sense other than a stylistic revival or product of market and advertising? In this sense, interpretative models of minimalism in architecture range from idealization to demystification. In any event, thanks to the time distance, the period ahead is left with the task of opening new interpretative models of minimalism, which can certainly be subjects of some future debates.

\section{BIBLIOGRAPHY}

AUER G. (1988) Vom Nutzen des Nichts: Minimalistische Formen und Formein in der Architektur, Daidalos (30) 96-109.

AVON, A., VRAGNAZ, G. (1988) Aspetti del minimalismo in architettura, Rassegna (36:4) 29-38.

BATTCOCK, G. ed. (1968) Minimal Art: A Crtical Anthology, Dutton, NewYork.

BERTONI, F. (1999) Claudio Silvestrin, Octavo, Firenze.

BERTONI, F. (2002) Architettura minimalista, La Biblioteca, Firenze.

BERTONI, F. (2006) Design minimalista e Claudio Silvestrin, Journal of the Museum of Applied Art in Belgrade (2) 91-107.

BONNEFOI, C. (1976) Louis Kahn et le minimalisme, Architectures-Arts Plastiques, ed. Y.A. Bois, Corda, Paris; 118-136.

BUCHANAN, P. (1991) Swiss Essentialists, The Architectural Review (1127) 19-12.

CARMAGNOLA, F., VANNI, P. eds (1996) Minimalismo: ettica delle forme e nuova semplicita nel design, Lupetti, Milano.

CELANT, G. (1988) La scultura, un'architettura non abitabile, Rassegna (36:4)16-28.

CURTIS, W. (1982) Modern Architecture since 1900, Phaidon, London. 
FOSTER, H. (1986) The Crux of Minimalism, Individuals: A Selected History of Contemporary Art 1945-1986, Museum of Contemporary Art, Los Angeles; 162-183.

FRAMPTON, K. (1983) Prospects for a Critical Regionalism, Perspecta: The Yale Arcitectural Journal (20) 147-162.

FRAMPTON, K. (1992) Modern Architecture: A Critical History, Thames and Hudson, London.

GLANCEY, J. , RICHARD, B. (1990) The New Moderns, Soma Books, San Francisco.

GOLDHAGEN, S. W. (2005) Something to Talk About: Modernism, Discourse, Style, JSAH (64/2) 144-167.

GREGOTTI, V. (1988) Editoriale: Minimal, Rassegna (36:4) 4-8.

GRIMMER,V., MRDULJAS, M. and A. RUSAN (2009) To Be Apstract Doesn't Mean to Be Minimalist: interview with architect Alberto Campo Baeza, ORIS online issue 55, <http://oa.upm.es/6812/2/INVE_ MEM_2010_74846.pdf>

GRIMSHAW, M. (2004) Soft Modernism: The World of Post-Theoretical Designer, Ctheory online journal article 140, <http://www.ctheory.net/ articles.aspx?id=418\#_ednref24>

HOLL, S., PALLASMAA, J., PÉREZ-GÓMEZ, A. (1994) Questions of perception: phenomenology of architecture, A+U Special Issue, Tokyo; Pallasmaa, J. (2005) The Eyes of the Skin: Architecture and the Senses, John Wiley, New York.

IBELINGS, H. (1988) Supermodernism, NAI Publishers, Rotterdam.

JENCKS, C. (1982) Current Architecture, Academy Editions, London.

JENCKS, C. (1987), Post-Modernism: The New Classicism in Art and Architecture, Academy Editions, London.

JENCKS, C. et al. (1990a) The New Modern Aesthetic, Architectural Design Profile (86)

JENCKS, C. (1990b) The New Moderns: From late to neo-Modernism, Academy Editions, London.

JENCKS, C. (2002) The New Paradigm in Architecture, Yale University Press, London, New Haven.

KRAUSS, R. (1996) The grid, the /cloud/, and the detail, Presence of Mies, ed. D. Mertins, Princeton Architectural Press, New York; 134-146.

KUSPIT, D. (1988) La versione minimalista dell'arte non-oggettiva, Rassegna (36:4) 38-49.

LINDER, M. (2004) Nothing less than literal: architecture after minimalism, The MIT Press, Cambridge.

MACARTHUR, J. (2000) The look on the object, Assemblage: A Critical Journal of Architecture and Design Culture (41) 48.

MACARTHUR, J. (2002) The look on the object: minimalism in art and architecture, then and now, Architectural Theory Review (7:1) 137-148.

MACARTHUR, J. (2005) The nomenclature of style: Brutalism, Minimalism, art history and visual style in architecture journals, Architectural Theory Review (10: 2) 100-108. 
MACHADO, R., EL-KHOURY, R., (1995), Monolitic Architecture, Prestel, Munich.

MALLGRAVE, H. F., GOODMAN D. (2011) Minimalisms, An introduction to architectural theory: 1968 to the present, Oxford, Wiley-Blackwell; 194-215.

MELHUISH, C. (1994) On Minimalism in Architecture, Architectural Design Profile (110) 8-14.

MEYER, J. ed. (2000) Minimalism, Phaidon, London.

MONTANER, J.M. (1993) Minimalismos, El Croquis (62-63) 4-23.

MURRAY, P. (1999) Something or Nothing: Minimalism in Art and Architecture, Architectural Design Profile (139) 8-17.

NICOLIN, P., ed (1994) Neominimalismo, Lotus International (81), Milan.

OBENDORF, H. (2009) Minimalism in architecture, in Minimalism: Designing Simplicity, Springer-Verlag, London; 54-56.

PALLASMAA, J. (2005) The Eyes of the Skin: Architecture and the Senses, John Wiley, New York.

PAWSON, J. (1996) Minimum, Phaidon, London.

PRESTINENZA, P.L. (2008) New Directions in Contemporary Architecture, London, John Wiley and Sons Ltd; 51-55, 85-87.

RILEY, T. (1995) Light Architecture, MoMa, New York.

RUBY, I. et al. (2003) Minimal Architecture, Prestel, Munich.

SMITH, C.R. (1976) The Mexican minimalism of Ricardo Legorreta, Architectural Record (160) 97-104.

TAKI, K. (1984) Minimalism or Monotonality? A Contextual Anallysis of Tadao Ando's Method, Tadao Ando: Buildings Projects Writings, ed. K. Frampton, Rizzoli International, New York; 11-22.

TOY, M (1994) Editorial: Aspects of minimal architecture, Architectural Design Profile (110) 7.

TOY, M (1999) Editorial: Aspects of minimal architecture II, Architectural Design Profile (139) 7.

TOY, M. (2000) Practically Minimal, Thames and Hudson, London.

VICE, P. (1994) Minimalism and the Art of Visual Noise, Architectural Design Profile (110) 15-17.

VANEENOO, C. (2011) Minimalism in Art and Design: Concept, influences, implications and perspectives, Journal of Fine and Studio Art (2/1) 7-12

VITTORIO, E.S., MONTANER, J. M. (1996) Less is more: minimalisme en arquitectura i d' altres arts, Collegi d' Arquitectes de Catalunya and Actar, Barcelona.

WOLLHEIM, R. (1965) Minimal Art, Arts Magazine (January 1965) 26-32.

YPMA, R. (1996) London Minimum, Thames and Hudson, London.

ZABALBEASCOA, A., MARCOS, J. R. (2000) Minimalisms, Editorial Gustavo Gili, Barcelona. 
Alındı: 10.09.2012; Son Metin: 10.12.2013

Anahtar sözcükler: mimarlıkta minimalizm, tasarlama, tüketicilik, modernizm, postmodernizm, minimal sanat.

\section{MIMARLIKTA MINIMALIZMIN YORUMLAYICI MODELLERİ ÜZERINE BIR OKUMA}

Mimarlıkta minimalizm 80'lerde ortaya atıldığından bu yana tartışmalı, kendine özgü bir konudur. Minimalizm üzerine söylem 90'larda yoğunluk kazanırken 21. yüzyılın ilk on yılının ortalarında kuramsal bir odak olmaktan yavaş yavaş çıkmaya başlamıştır. Mimarlıkta minimalizmin bir kökeni ve süregelen bir gelişmesi olmadığından ve çok az mimar kendini minimalist ilan ettiğinden, tartışma tarz, eğilim, akım ya da okuldan bağımsız olarak sürmüştür. Demek ki, mimarlıkta minimalizm postmodern dönem ve sonrasında varolan ve yaygınlaşan biçimsel deyimi açılama ihtiyacından doğan mimari bir söylem olarak da nitelendirilebilir. Önerilen araştırma çerçevesinin amacı, yorumlayıcı modelleri okuyarak, mimarlıkta minimalizmin tarihinin kuramsal bir tarih olduğunu öne süren çağdaş mimarlığı daha iyi anlayabilmektir. Bu nedenle çağdaş mimarlık araştırmacısı, minimalizmin, ne sadece biçimsel yapısının açıklanması, sınıflandırılması, şiirsel çözümlemesi, hatta ne de yalnızca minimalizmin ortaya çıkışını toplumsal ve tarihsel bağlama dair sorunlarla yüzyüze gelir. Herşeyden önce bir dizi muğlak kuramsal yorumlara karşı eleştirel bir bakışa sahip olmak gerekiyor.

VLADIMIR STEVANOVIĆ; B.Arch

Dipl. eng. Arch., Associate Assistant, Department of History, Theory and Aesthetics of Architecture and Visual Arts, Faculty of Architecture, University of Belgrade, Serbia. 